Saint Louis University School of Law

Scholarship Commons

All Faculty Scholarship

2018

\title{
The Financial Counseling Industry: Past, Present, and Policy Recommendations
}

David A. Lander

Saint Louis University School of Law

Follow this and additional works at: https://scholarship.law.slu.edu/faculty

Part of the Consumer Protection Law Commons

\section{Recommended Citation}

The Financial Counseling Industry: Past, Present, and Policy Recommendations. Journal of Financial Counseling and Planning, Vol. 29, No. 1, 2018.

This Article is brought to you for free and open access by Scholarship Commons. It has been accepted for inclusion in All Faculty Scholarship by an authorized administrator of Scholarship Commons. For more information, please contact erika.cohn@slu.edu, ingah.daviscrawford@slu.edu. 


\section{S A I N T L O U IS}

$\begin{array}{llllllllll}U & N & \text { I } & V & E & R & S & \text { I } & T & Y\end{array}$

\section{SCHOOL OF LAW}

\section{SAINT LOUIS UNIVERSITY SCHOOL OF LAW Legal Studies Research Paper Series}

No. $2018-3$

The Financial Counseling Industry: PAst, Present, AND

POLICY RECOMMENDATIONS

David A. Lander

Saint Louis University

Journal of Financial Counseling and Planning

Volume 29, Issue 1, pp. 163-174 (2018) 


\section{The Financial Counseling Industry: Past, Present, and Policy Recommendations}

\section{David Landera}

Financial counseling plays an important role for low-and moderate-income Americans and deserves more attention from leaders in the field. As financial counseling has evolved, the providers have been challenged to find a model that is both borrower centered and sustainable. This article provides a diagnosis of the failures and challenges in the financial counseling field, as well as a discussion of steps through which the providers could optimally serve families in need. These steps include (a) enhanced funding of the industry as a result of a recognition by financial stakeholders that it would be beneficial for them if the counseling industry was markedly improved; (b) stronger training for counselors; (c) implementation of enhanced measurement tools so that both funders and consumer borrowers could choose their providers from an informed position; and (d) assertion of leadership by consumer advocates and the Consumer Financial Products Bureau in improving this industry.

Keywords: counseling, financial distress, foreclosure, credit cards, bias, student loans

I $\mathrm{n}$ the 1990s, millions of Americans needed counseling and education to help them with their overdue credit card balances. A decade later, millions needed counseling and education to help them avoid foreclosure on their home mortgages. Today, additional millions of Americans need help with the excessive balances on their student loans and other debts. In the face of the desperate need for these services, much of the financial counseling industry lacks the essential elements necessary for meaningful relief, and there is currently no credible momentum toward more effective financial counseling. In order to move to more effective financial counseling

1. Academic institutions must strengthen counselortraining paths.

2. Measurement and reporting mechanisms must be created and required so that funders and consumers can identify those providers that offer the most effective help.

3. Financial stakeholders must realize it is in their economic interests to fund these improvements.

4. Third-party watchdogs must step forward to lead and monitor an effort similar to the way the National Consumer Law Center (NCLC) and
Consumer Federation of America (CFA) stepped up to lead the industry out of chaos in 2003.

This article provides an explanation of why current services are so weak, a road map to effective counseling, and a shout-out to the financial stakeholders and consumer advocates to reform the industry.

Counseling of low- and moderate-income consumers in financial distress is part of a spectrum of financial education and counseling and coaching services. On the noncrisis side of this continuum are three efforts: financial literacy education, which begins in elementary school and continues in $\mathrm{K}-12$ and into college and after college for the first-time homebuyer; savings programs, which have gained enormous momentum worldwide in the past few years with the creation and spread of individual development accounts (Burhouse, 2010; Grinstead, Mauldin, Sabia, Koonce, \& Palmer, 2011); and financial coaching, which is the name given to the rapidly emerging process of helping to guide a consumer client who is not in crisis to make wise decisions (Carlson, 2014; Collins, 2014; Lienhardt, 2015). On the crisis side of the continuum is financial counseling. According to the Oxford Dictionary, 
the definition for counseling is "the provision of assistance and guidance in resolving personal, social, or psychological problems and difficulties." Financial counseling plays a key role in dealing with crises, navigating processes, and mediating between parties (intra-household) as well as between creditors and borrowers. Counseling is critical when families are in trouble.

The obvious and primary difference between the sides of the continuum is that unlike the clients who are not in crisis, the counseling clients are in acute financial difficulty, which they cannot solve without guidance and the right tools. This acute difficulty creates crises for the clients but may also create a "teachable moment," which could lead to productive behavior change if that is part of the solution.

\section{History of Counseling of Borrowers in Financial Distress}

To create a better future for counseling of low- and moderate-income consumers in financial distress, we must understand the disappointing past and present.

\section{History Phase 1: Credit Card Lenders Create Consumer Credit Counseling Services}

As credit card debt grew in the late 1960s and as defaults began to constrain creditor profits, a subset of these creditors invented an industry to "help" their borrowers pay the money they owed to the creditors. Some of their rationale was eleemosynary, and some was to increase the profits of the creditors by inventing something that was part collection agency and part social service agency. In a few geographical areas, these newly organized CCCSs were housed in an existing United Way-sponsored nonprofit family and children service agency. The vast majority, however, were start-up nonprofits that were initially controlled by the creditors and identified more with creditors than with consumers. In the beginning there was a dearth of quality control, effective training, or identification with the client, and no follow-up sessions.

Funding is always essential to creating a sustainable helping organization. From 1970 to 2000, the new organizations were very well funded by a debt management plan (DMP). The clients who signed up for a DMP received valuable interest rate concessions and installment concessions from many of their creditors. The "counseling agency" received funds to pay the creditors from the debtor or directly from the debtor's employer and transmitted those dollars due under the DMP to the creditors. In return, many of those creditors rebated what were designated fair share payments to the credit counseling agency for creating and administering the DMP. These dollars funded the agency. For some years, most large creditors happily paid a fair share of up to $15 \%$ of collections because they recognized that it was in their financial interests. That outlay was less than the creditors would have had to pay to a traditional debt collection agency and perhaps the customer would work herself out of default and borrow again.

Even as the DMP thrived, however, its inherent weaknesses created serious problems and introduced significant bias into the determination of whether the consumer simply needed advice, needed a DMP, or needed to be referred for a bankruptcy or other third-party service. First, the client who needed advice only but not a DMP generated less revenue to the agency, so there was an incentive to sell that client an unneeded but revenue-positive DMP. The sale of an unneeded DMP required the creditor to pay fair share and grant concessions to a borrower for whom the concessions were not necessary. Second, virtually no credit counseling agency was willing to refer a client to a consumer rights attorney or mention bankruptcy even when the DMP would likely fail because the client had too much debt and not enough income. Because bankruptcy resulted in losses to creditors, it became anathema to the agencies the creditors created. Therefore, clients who could have been able to save their cars or houses or apartments by using their dollars strategically might have been directed by the agency to pay the credit card lender even though they could never dig out of debt. Such clients would sacrifice their car or apartment or home unnecessarily because dollars that could have saved their housing or transportation were paid under the DMP on credit cards. The credit card debt could have been discharged in bankruptcy.

As conventional credit card debt exploded in the 1980s and as subprime credit exploded in the early 1990s, defaults increased exponentially and more consumers called the agencies and purchased DMPs. Fair share payments became a larger expense item for creditors and generated many more dollars for the agencies. Few of the larger counseling agencies used these dollars to develop techniques that would be more effective for the consumer.

At this same time, the consumer credit industry was consolidating, and the larger creditors saw an opportunity to reduce their collection costs by developing more sophisticated 
proprietary methods of collecting. This reduced the value of a DMP to the creditors. The larger creditors reduced fair share payments drastically and began to police the industry by raising the eligibility requirements for a DMP. These creditors reduced the size of the concessions they granted to consumers under a DMP. They also dramatically punished agencies that sought DMP status for consumers who did not meet their criteria. Prior to these changes in the 1990s, the honest larger efficient providers were able to develop very significant surpluses (Lander \& Loonin, 2005). Some providers used these dollars to expand and modernize or fund educational foundations or projects, others to pay larger salaries to their executives and/or build very large fund balances. These providers have subsequently searched for other funds to replace the reductions in fair share dollars, but they have not found a dependable and continuing source.

Once the value of the DMPs was reduced and creditors developed policy mechanisms for making sure no DMPs were provided for people who needed "advice only," many of the less efficient providers began to sustain losses. The larger providers shifted from in-person sessions to telephone banks or online interviews. These larger providers gobbled up their competitors in a series of nonprofit rollups (Williams, 2013). This consolidation has continued to the present with Clearpoint and Atlanta, two of the larger organizations merging in 2015; in 2017, that merged organization announced that it would merge with Money Management International (MMI), the largest organization. More and more of the remaining large providers look like for-profit enterprises (Williams, 2014).

Today there are several large agencies that service a high percentage of the clients and many smaller agencies that serve the remainder. The compensation for the chief executive of each of the 10 largest organizations in 2014 ranged from well over a million dollars to $\$ 250,000$, and the average compensation for the chief executive of the top 10 organizations was $\$ 540,000$ (Williams, 2016). This model is subject to a series of limitations that severely reduce the effectiveness and value of the services it is able to provide (Williams, 2013). These limitations include

1. Unrealistic restrictions on the amount of time that a counselor may spend with the client. There is almost always only a single session with no meaningful follow-up
2. Lack of sufficient third-party evaluation and insufficient data collection

3. Very limited referral to legal counsel for bankruptcy or for violation of consumer protection laws

4. Insufficient counselor training or educational standards for a job that requires both teaching technical skills and counseling techniques

5. Lack of sufficient monitoring and quality control with regard to the counseling and educational aspects of the session

Although these large organizations dominate the marketplace, local community-based traditional nonprofit social service providers do thrive in various locations. During the foreclosure crisis, locally based community development corporations and other neighborhood organizations stepped forward to help, and many have continued to provide these same services. In addition, the Annie Casey Foundation and the Robin Hood Foundation are engaged in funding financial counseling through strong nonprofit organizations. Finally, in some areas, credit unions have created community development financial institutions (CDFIs), and Cities for Financial Empowerment has funded organizations that provide coaching and financial literacy education. Although many of these providers are very small, they look much more like helping organizations than the larger historic CCCS entities.

\section{History Phase 2: Creation of Foreclosure Mitigation and Counseling Programs}

Although the explosive increase in credit card debt presented a major concern to individual consumer borrowers, it pales by comparison with the level of consumer mortgage debt, both on a micro and a macro level. On a micro level, foreclosure and eviction are usually much more serious than a judgment on a credit card debt; on a macro level, total mortgage debt is more than 10 times the total of credit card debt.

Pre-2007 Foreclosure Counseling. American public policy has long favored home ownership and has often offered special opportunities and incentives to first-time home buyers. In order to take advantage of these benefits, first-time buyers are usually required to participate in prepurchase counseling programs. The modern housing counseling industry came into existence in the 1960s and was rooted in the goal of helping low- and moderate-income families succeed as homeowners (Quercia \& Cowan, 2008a; Quer- 
cia \& Spader, 2008b). In 1968 when the Department of Housing and Urban Development (HUD) sought to extend mortgage financing to riskier borrowers through Section 235 and other programs, prepurchase counseling of these first-time home buyers was to be a key component. In the 1970s, prepurchase counseling was extended to various Federal Housing Administration (FHA) home buyers. The counseling was provided by contract with private or public organizations. Initially, no money was authorized, but in 1977 in the face of rising defaults, about 3 million dollars were appropriated to pay for the counseling. The providers ranged from neighborhood nonprofit community development corporations to regional financial centers and included a portion of the original CCCS organizations. Prepurchase counseling was expanded as government-sponsored enterprises (GSEs) such as Fannie MAE and Freddie MAC implemented goals of increasing home ownership, by the Community Reinvestment Act (CRA) requirements and by the establishment of the HOME Program in the 1990s (Olson, 2007). In 1999, HUD-certified providers held more than 200,000 prepurchase counseling sessions, a 10-fold increase over 1994 (Herbert, Turnham, \& Rodger, 2008).

The criteria for a provider to obtain HUD certification included nonprofit status, a local community presence, experience administering housing counseling programs for at least a year, and an automated client management system for collecting and reporting client-level data. Although HUD does not set service standards for agencies, it does require that the counseling staff have some training and experience and that the agency have counselors who are fluent in the language of the clients.

Currently there are approximately 1,800 HUD-approved counseling agencies of which 1,200 are funded by HUD. HUD also invests 3 millions dollars annually to train counselors for agencies participating in the programs. There are, of course, many more providers that are not HUD approved (Quercia \& Cowan, 2008a; Quercia \& Spader, 2008b).

Post-2007 Mortgage Default Counseling. Foreclosure mitigation counseling exploded with the onset of the 2006 rash of mortgage defaults. In response to the massive glut of foreclosures, the Federal Government developed several complicated programs that offered options to homeowners who were in default on their mortgages. As it became clear that most homeowners in danger of foreclosure needed help in qualifying for these programs, HUD and Fannie MAE identified and contracted with organizations to provide diagnostic and counseling services. Initially the program called for the large national telephone providers to do an initial screening and for the local face-to-face counselors to do more intensive follow-up. Over time, this shifted and each network attempted to do the entire range of diagnosis and counseling. Just as with credit card lenders, the larger mortgage lenders and debt owners often favor the larger phone bank providers over the community-based providers because their nationwide coverage makes them easier to deal with.

In 2007, Congress selected NeighborWorks America to administer the newly initiated National Foreclosure Mitigation Counseling program. NeighborWorks America is a congressionally chartered nonprofit organization that supports community development in the United States and Puerto Rico. NeighborWorks America provides training for housing and community development professionals through its national training institutes (Collins \& Schmeiser, 2012). In a continuing effort to assist in recovery from the housing crisis, NeighborWorks America launched the Loan Modification Scam Alert Campaign and Stable Communities Initiative in 2009. In June 2011, HUD, in partnership with NeighborWorks America, launched the Emergency Homeowners' Loan Program to assist homeowners across the country at risk of foreclosure. This network of mortgage default counseling providers includes those nonprofits that started as credit card counseling/DMP agencies as well as a host of neighborhood nonprofit organizations, regional nonprofit financial education centers, and national networks supported by foundations. So long as these providers satisfy the minimum HUD requirements, there have been few ways other than word of mouth for the client to differentiate among them by effectiveness or quality. They vary from neighborhood community development corporations that provide a host of social services for local residents to large credit card counseling nonprofits that serve thousands of clients around the country through large telephone banks. Characteristics such as client focus, counselor skill set and experience, effectiveness of follow-up, and ease of referral to legal counsel or other required referral are important differences among providers (Collins \& Schmeiser, 2012; Jefferson, Spade, Turnham, \& Moulton, 2012; Lind, 2011; Mayer, Tation, Temkin, \& Calhoun, 2012). Foreclosure counseling has similarities with and differences from traditional credit card counseling. A crucial and complicating 
component of mortgage counseling is the determination of which available federal mitigation program is best for the client. This is similar to DMP diagnosis but much more complicated (Cox, 2008).

These foreclosure mitigation programs are often confusing and require constant follow-through with the mortgagees and servicing agents. Some of the providers included traditional education and behavior change components in addition to the required diagnosis. Between 2008 and 2011, Congress appropriated $\$ 508$ million for default mortgage counseling through the National Foreclosure Mitigation Counseling Program (Collins \& Schmeiser, 2012). For several years these dollars replaced the falling DMP revenue in the budgets of the historic credit card network of providers. For example, in 2010 MMI reported government grants of $\$ 20,517,629$ including 9 million dollars received through NeighborWorks America intermediaries and \$8,920,366 from the U.S. Department of the Treasury. Some of these dollars may have been for first-time homebuyer education. In 2012, GreenPath reported government grants of $\$ 7,499,747$, and Atlanta CCCS reported revenue of $\$ 9,335,109$ from government grants. Atlanta merged with Clearpoint in 2014 and the merged entities' website indicates the combined entity was the largest provider of these services. Receipt of revenue from these foreclosure counseling activities was particularly timely for CCCS organizations since Congress and the Internal Revenue Service had determined that the CCCS organizations could not retain their tax-exempt status if DMP revenue constituted too large a percentage of their total revenue (Lander \& Loonin, 2005). Forfeiture of this status is a bar to providing credit counseling services in most states.

There are now more than 240 NeighborWorks America-affiliated organizations operating in urban, suburban, and rural communities in all 50 states, the District of Columbia, and Puerto Rico. NeighborWorks America has become a leading trainer of community development, financial capability, and affordable housing professionals. NeighborWorks America and its affiliates have helped more than 1.7 million homeowners through its congressionally funded National Foreclosure Mitigation Counseling program. Several other intermediaries such as HomeFree-USA and the National Council of La Raza also provide valuable services. About half the borrowers receive their counseling in person and half by phone or Internet. Many of the neighborhood-based providers offer the first session in person with follow-ups by phone and/or the Internet.
Studies have shown that homeowners who obtained help from intermediaries such as NeighborWorks America and the National Council of La Raza and HomeFree had a greater chance of remaining in their homes (Collins \& Schmeiser, 2012). Unfortunately, however, none of those studies provides sufficient information from which consumers or funders can make an informed choice among the wide range of providers. During the height of the crisis, these counseling services were primarily funded by federal dollars; as the crisis abated, federal funding was reduced and many providers today lack the resources to counsel those homeowners who need their help.

\section{History Phase 3: Student Loan Counseling Is Evolving to Try to Respond to the Student Loan Debt Crisis}

Just as credit card defaults exploded in the 1990s and mortgage defaults exploded in 2006 and 2007, student loan debt and then distress on that debt exploded in 2010 and has continued unabated. There are important similarities between distressed student loan counseling and mortgage loan default counseling. The key similarity is that, in each case, determining which of the programmatic alternatives is best for the client is complicated and essential. Another similarity is that there is confusion about the role of the debt servicers or intermediaries. In both instances, public policy began with reliance on the debt servicer or intermediary to "help" the borrower in financial distress. In both instances, this was a damaging mistake since the servicer or intermediary works for the creditor and not the borrower and does not have an economic incentive or instinct to help the borrower. In some ways, it is reflective of the bias that prevailed in the credit counseling industry until 2000 and that continues to prevail with many of the providers today. Consumers in financial distress greatly need unbiased advice and recommendations.

Initially the Department of Education and the Consumer Financial Protection Bureau (CFPB) mistakenly expected the student loan borrowers to be able to figure out the process on their own by using the materials that the Department of Education posts and by using third-party websites such as www.studentloanborrowerassistance.org. It soon became clear, however, that the process was too complex for many borrowers to be able to negotiate on their own, but there were no legitimate financial counseling organizations equipped to help. As an experiment, the Center for Excellence in Financial Counseling launched a 2-year program in which three financial counseling providers with excellent reputations 
were funded to offer counseling services to consumers with distressed student loan debt. These programs required fullscale counselor training and included follow-up sessions, easy referral to attorneys, data gathering, intense quality control, and a rigorous counseling component (Jacobson, 2016). More recently, both the National Foundation of Credit Counselors (NFCC; Williams, 2015) and NeighborWorks America have launched student loan borrower counseling programs. It is uncertain whether the programs being launched by the NFCC and NeighborWorks America will include the necessary components. Over time, the desperation of deeply indebted student loan borrowers has encouraged many offers of help, some well-intentioned and some not (Collins \& Schmeiser, 2012). There are a great many websites and other advertisements that purport to offer help. At this point, the student loan network seems considerably weaker than the NeighborWorks America network on foreclosure counseling during the height of the housing crisis. Moreover, no significant funding has emerged to cover the cost of student loan counseling as the financial stakeholders have not stepped forward.

\section{Reforms That Are Necessary for the Professional Financial Counseling Industry to Be Effective Reform \#1: Training for a Career as a Professional Financial Counselor for Low- and Moderate-Income Consumers Must Be Improved}

The quality of financial counseling is dependent on the quality and expertise of the counselors (Griffiths, Baxter, \& TownleyJones, 2011). Currently the training and education network for financial counselors and coaches is limited and diffuse (Lienhardt, 2015) and there is virtually no professional training path to a career as a financial counselor of consumers in financial distress. In order for the industry to prosper and for more providers to improve their quality and effectiveness, there must be a stronger and more well-defined system of training. First, it is necessary to understand the array of skills needed to counsel these consumers. Financial counselors must have the patience to listen and the knowledge to counsel, educate, and diagnose (Rowley, Lown, \& Piercy, 2012).

A low- or moderate-income consumer in financial distress first needs the unbiased diagnosis, which will determine the level and type of services that should be offered. These services might include advice only, a DMP, one of the remedies available for mortgage remediation or student loan repayment restructure, and a possible referral to a mental health hotline or to a bankruptcy or a consumer rights lawyer. Then, the counseling, which, depending on the diagnosis, situation, and client, might include budgeting advice, financial literacy education, behavior change counseling, and/or an appropriate referral.

Because there has not been any robust career track, no effective training programs have been created to equip aspiring students with the necessary counseling and technical budgeting skills. In a classic "chicken and egg" dilemma, the lack of pre-career educational lines for counselors constitutes a serious barrier to the efforts of service providers to become more effective. Because it is instructive to understand the limited training and educational resources that do exist, I present the following survey of these resources.

A very interesting academic development is occurring at the City University of New York (CUNY). As part of its effort to build financial counseling expertise within city offices and nonprofit neighborhood organizations, the New York City government worked with CUNY to develop a short-term "Boot Camp" program for employees in nonprofits who provide financial counseling for their clients. As the program grew and matured, that short-term boot camp transitioned into two three-credit courses, which are offered on an ongoing basis. This is growing into an area of concentration aimed directly at the "professionalization" of financial counseling for low- and moderate-income consumers. Currently, similar courses are being offered in most of the regions to which Cities for Financial Empowerment has spread its dollars. Maintaining quality control on these courses will be a crucial challenge.

The current curriculum of these courses includes acquiring basic knowledge of budgeting, debt, banking, credit scores, counseling skills, and negotiation skills.

\section{On-the-Job Training or Continuing Education for Fi-} nancial Counselors. The quality of continuing education training in the credit counseling systems has been very uneven. In the student loan borrower counseling arena, the training has been nonexistent except for several training programs organized by the Center for Excellence in Financial Counseling and provided by the NCLC. There has been a more significant effort, both in quality and quantity in the mortgage foreclosure arena. For example, NeighborWorks (http://www.neighborworks.org/Train- 
ing-Services) and several other housing networks including HomeFree-USA and the National Council of La Raza have extensive relevant high-quality training programs, which have included topics such as counseling and foreclosure avoidance.

Social Work Schools. Social workers regularly come in contact with people who need financial help. Their contact may consist of helping with filing for the earned income tax credit or helping the client manage within her limited income. In the early years of the field of social work, "financial social work" and "financial well-being" were deemed important and were integrated into the training curriculum (Sherraden, Jacobson, \& Birkenmaier, 2016). Over time, however, the field of social work education and the supporting educational curriculum turned away from economics and focused on mental health and psychological interventions. To a large extent, this mental health focus continues today. Thus, although there was a time when social work curriculum included a financial education component, that component disappeared. Beginning at the end of the 20th century and accelerated by the financial crisis of the Great Recession, some social work professors began renewing their attention on financial well-being. In the past several years, important additions have been made to the undergraduate and graduate social work curriculum at a number of universities. Several social work schools have developed or are developing stand-alone financial capability courses or financial social work as a field of concentration to integrate the content into social work theory and practice (Sherraden et al., 2016).

College and University Courses-Family Life Education. As financial training receded from the social work curriculum, departments at some land grant universities including Texas Tech, Oklahoma State, Georgia, Iowa State, Kansas State, Missouri, and Wisconsin stepped in to fill the gap. The departments are variously named "family life education," "family economics," "human ecology," or "personal financial planning." Thomas Garman, a pioneer who mentored a number of the current leaders in the field, cowrote the standard texts. These departments offer technical courses focusing on software; some offer "soft-side" courses on personal and counseling skills. Currently most of the courses are aimed at financial planning for people of moderate or high incomes and that field of study is well developed.
Several schools offer a few courses for those students who are planning to work with low- and moderate-income consumers. These students might be headed to careers in military financial counseling (Carlson, Nelson, \& Skimmyhorn, 2016) or to work in community development corporations or CDFIs. Even in those schools, the courses being offered are scattered among different parts of the university, which impedes coordination. A major effort will be required to strengthen existing programs so that sufficient resources are aimed at distress counseling.

Development of the field needs MA and $\mathrm{PhD}$ programs designed to train those who will be teaching the future counselors at community colleges, social work schools, and college BA programs. In addition, robust graduate studies would help remedy the lack of sufficient quality research and writing.

\section{Reform \#2: Measurement Tools Must Be Developed and Required in Order to Identify the Most Effective Pro- grams}

The low- or moderate-income consumer in financial distress confronts a very confusing landscape when she seeks financial counseling (Hunt, 2005; Wilshusen, 2011). The borrowers' available choices differ greatly from those of consumers seeking other types of social services. Consumers in financial distress must choose among the heavily marketed large phone bank providers that developed from the model of the credit card counseling agencies on the one hand or from the local or regional providers that developed from very different models on the other hand. In order to assess the effectiveness of individual providers, it is crucial for consumers, creditors, regulators, and funders to obtain accurate objective sources of information about the effectiveness of providers and their products (Grable \& Joo, 2001; Wilshusen, 2011). Standards that do exist within the HUD approval process, such as the 2005 Benchmarks Agreements on housing counseling, and the existing credentialing of counselors and the Council of Accreditation standards for providers, are minimum standards. These standards do not differentiate sufficiently by quality or effectiveness. Uniform systems of measurement need to be established and enforced for both financial counselors and credit counseling organizations (Dew \& Xiao, 2011).

Regulators are developing such measurement tools for other types of social services. Three examples are the data that hospitals are required to publish regarding the results of various 
kinds of procedures or the treatment of specified diseases; the prevention status reports administered by the Centers for Disease Control and Prevention; and the tools for evaluating social service activities such as the effectiveness of the creation of Head Start. A similar requirement for credit counseling organizations would provide information that is vital in order for the consumers and funders to make a sound decision. (Kim, Garman, \& Sorhaindo, 2003).

Although there are several studies that analyze the impact of mortgage forbearance programs (Collins \& Schmeiser, 2013; Mayer et al., 2012) and the impacts of DMPs (Britt, Canale, Fernatt, Stutz, \& Tibbets, 2015; Dobbie \& Song, 2015; Elliehausen, Staten, \& Lundquist, 2007; Roll \& Moulton, 2016), these studies provide little or no information to help the consumer in distress make an informed choice regarding the most effective provider. Likewise, these studies provide insufficient information for funders or debt holders to determine which providers to support. They do however identify some measurement tools that may be useful in suggesting the types of data that should be required from providers. I will now provide several examples of measurement guideposts and suggestions.

1. A study by the City of New York developed an assessment guidepost that included employment and other measures of life success (New York City Department of Consumer Affairs, 2014).

2. A study of homeowners with negative equity followed the lives of borrowers who had received counseling and compared them with noncounseled similar homeowners to measure various life success standards such as job placement rates and salary after 1 year of employment (Fedaseyeu \& Hunt, 2015).

3. Collins and O'Rourke have suggested that a 2- or 3-year follow-up FICO measurement would be valuable (Collins \& O'Rourke, 2011).

4. A DMP study used future credit scores or filing for bankruptcy as measurement tools (Barron \& Staten, 2011; Elliehausen et al., 2007).

5. One study reviewed the data gathered from a project for counseling borrowers with defaulted student loans that included a counseling component based on the 5A model (Public Policy Research Center, University of Missouri St. Louis, 2014).
6. The work of Professors Xiao, O'Neil, Prochaska, and others tested the use of the Transtheoretical Model of Change during credit counseling sessions (Xiao et al., 2004b).

7. Applying the Transtheoretical Model of Change to Debt Reducing Behavior. Financial Counseling and Planning, 15(2) (Xiao et al., 2004a). A Consumer Education Program Based on the Transtheoretical Model of Change. International Journal of Consumer Studies, 28(1), 55-65. The credit counseling industry was offered the opportunity to embrace the Transtheoretical Model but rejected the opportunity.

8. Another study provided rigorous measurement of a pilot coaching effort in 2010-2012, a onetime, 60-minute coaching session during which counselors worked one-on-one with consumers to complete critical steps. This program used insights from behavioral science (Davis \& Kim, 2016).

9. Possible associations of financial anxiety were explored using a sample of 180 college students who sought services at a university peer financial counseling center (Archuleta, Dale, \& Spann, 2003).

In recent years, Single Stop centers funded by the Robin Hood Foundation have been working to improve methods of measurement that would allow differentiation. This is a very important program and hopefully will provide mechanisms that other funders can use.

\section{Reform \#3: Lenders, Government, and Foundations Must Value More Effective Counseling and Be Willing to Fund the Necessary Improvements}

In order to take the necessary steps to improve the quality and effectiveness of distressed debt counseling, stakeholders must provide the funds necessary to rebuild the system. Increased funding must include both the cost of diagnosis and counseling and the cost of strengthening the essential training and research underpinnings. Severe reduction in all revenue sources is a major factor in the mergers of the historic providers.

Although the creation of the DMP led to serious problems for both consumers and creditors, it did fund the provision of certain potentially valuable services for nearly 30 years. The large creditors' willingness to rebate fair share and to provide 
concessions reflected their recognition that an investment in counseling and appropriate enrollments in a DMP paid off in several ways (Xiao \& Wu, 2008). More effective counseling will increase the amount of repayment of debt from the consumer to the creditor and will help rehabilitate the borrower to become more productive and potentially more profitable in the future.

During the height of the foreclosure crisis, funding was available for mortgage foreclosure counseling because both financial stakeholders and the government realized how productive the funding was. Today, however, there is a serious shortage of funding to counsel consumers facing foreclosure. Moreover, no significant funding has emerged to help distressed student loan borrowers.

In addition to the profitability of financial institutions, there are at least two other reasons to support more effective financial counseling. The U.S. economy is heavily dependent on consumer spending. More effective rehabilitation of consumers in financial distress will be a direct benefit to consumer spending and the health of the U.S. economy. Also, as demonstrated during and after the Great Recession, government and foundations have an interest in restoring the mental health of the consumers in financial distress and the strength of their neighborhoods. In recent years, foundations such as Annie Casey and Robin Hood have invested millions of dollars into small neighborhood counseling providers. The U.S. military has long recognized the value of effective counseling to its members (Carlson, 2014; Carlson et al., 2016). Hopefully foundations and other funders will follow. More effective measurement tools should build trust among creditors, government, and foundations that increased funding will be an investment that will bring healthy financial returns as well as human benefits.

\section{Reform \#4: Third-Party Watchdogs Must Step Up to Lead and Monitor This Effort Similar to the Way That The NCLC and CFA Stepped Up to Lead the Industry out of Chaos in 2003}

A crucial concern is who will draft, oversee, and enforce the uniform reporting requirements and other necessary reforms. When the prospect of increasing revenue led for-profit corporations masquerading as nonprofits to make deep inroads into financial counseling, reformers within the industry reached out to the CFA for help. CFA reached out to the NCLC and, together, CFA and NCLC succeeded in obtaining action by the government to drive most of the profiteers out. When the NCLC and the CFA withdrew from this role as watchdogs of the industry, no one stepped in (Loonin \& Plunkett, 2003). Thus, no one was there to oversee the flood of dollars into the industry for foreclosure counseling. The U.S. Trustee within the Justice Department, HUD, GSEs, and the Federal Trade Commission play a portion of the watchdog role by setting minimum standards, but none of these organizations has helped the borrowers or funders to differentiate among providers that meet the minimum standards. It is once again time for organizations such as CFA and NCLC and involved foundations such as Annie Casey and Robin Hood as well as the CFPB to lead such an effort and institutionalize the new structures. Other social service providers and members of the Association for Financial Planning and Education (AFCPE) should step up to help insure effectiveness of these services.

The CFPB seems to have been created to serve this function, but even in its years of strongest performance the Bureau has been unwilling or unable to break the logjam of limited and low-quality services. If the CFPB survives intact, then it is past time for them to step forward and lead this industry to a better place.

Accreditation of both counselors and providers is necessary, but once again simply accrediting programs sets a minimum standard. In response to the mortgage foreclosure counseling programs, the battle to be the accrediting organization is reaching a fevered pitch. There are two separate sets of accreditation standards currently operating in this industry: the certification of the individual counselors and the accreditation of the organizations for which the counselors work. Providers that belong to at least one trade organization, the National Foundation for Consumer Counseling (NFCC), must obtain and maintain accreditation by the Council on Accreditation (COA). $\mathrm{COA}$ is an independent third-party not-for-profit accrediting organization that has reviewed more than 1,500 social service programs to ensure compliance with practice standards. All NFCC member agencies must be reaccredited by COA every 4 years. Once again, these are entry standards and there has been very little work on establishing levels of effectiveness beyond the entry point. COA has not displayed the inclination or expertise to develop and implement such an enhanced accreditation program. It would be very valuable for COA to develop a separate "blue ribbon" standard. Some years ago, the industry worked with CFA and others on such a standard, but the voluntary agreement broke down as it was 
being completed. The National Commission on Certifying Agencies (NCCA), the accrediting body of the Institute for Credentialing Excellence, has accredited the Association for Financial Counseling \& Education (AFCPE)'s AFC certification for a 5-year period, expiring December 31, 2020.

\section{Conclusion}

Tens of millions of dollars were disbursed to credit counseling organizations during the foreclosure crisis to keep borrowers in their homes. Although these funds supported services that helped many borrowers, two important opportunities were missed: first, the opportunity to provide borrowers and funders with information necessary to be able to determine which providers to support; and second, the opportunity to impose higher standards on the providers that received these dollars. Some of the largest providers still lack essential ingredients necessary for effective counseling such as follow-up sessions, quality control, and referral of the borrower to counsel. Newer smaller neighborhood-based organizations or CDFIs may offer opportunities not previously available and take a larger share of the market away from inferior, larger organizations that market more effectively.

The current student loan crisis and the continuing level of default on consumer loans constitute a window of opportunity and necessity. This effort is especially timely because historic providers are expanding into distressed student loan borrower assistance without sufficient safeguards and quality (Williams, 2015).

Now is the time for the CFPB and consumer advocates and for the financial stakeholders and guarantors of debt, and for members of AFCPE to take specific actions and to support these reform efforts. The financial stakeholders, philanthropic sector, government, and universities must wake up to this reality and develop ways of improving this industry. To provide clients and funders the information with which to make informed selection decisions, the providers must collect key uniform data and must publish third-party evaluation data. This will allow the public and funders to march to the better providers and away from those that are not effective.

\section{Call to Action}

1. Regulators and funders must force the development of and access to standard reporting systems, which will form the basis for consumer and funder selections. Accreditation and licensing officials must develop procedures to differentiate the best and most effective from the rest of the providers and must create a "blue ribbon" demarcation that the public and funders will understand and to which they will respond.

2. Educators within universities must create a training path for professional financial counseling of low- and moderate-income consumers in financial distress. Existing training and educational paths for financial counselors must be strengthened. Interested students need to be guided through BA, BSW, and MA and MSW programs. $\mathrm{PhD}$ programs must be expanded to provide a teaching base for this discipline and to provide dissertation and other independent research.

3. Lenders, guarantors, government, and foundations must provide the funding necessary to support more effective counseling to distressed consumers.

4. AFCPE members, CFA, NCLC, and foundations, and the CFPB must develop an effective institutional watchdog to assure careful monitoring and forward steps.

Improving the effectiveness of financial counseling will bring enormous economic and humanitarian benefits, which have been too long delayed. It is past time to mount a campaign to bring the necessary improvements to the training, to the measurement, and, most of all, to the counseling itself.

\section{References}

Archuleta, K. L., Dale, A., \& Spann, S. M. (2003). College students and financial distress: Exploring debt, financial satisfaction and financial anxiety. Financial Planning and Counseling, 24(2), 50-62.

Barron, J. M., \& Staten, M. (2011). DMP Participation and credit counseling outcomes. Retrieved from http:// www.frbsf.org/community-development/files/4-statenpaper.pdf

Britt, S. L., Canale, A., Fernatt, F., Stutz, K., \& Tibbets, R. (2015). Financial stress and financial counseling: Helping college students. Journal of Financial Counseling and Planning, 26(2), 172-186.

Burhouse, S. (2010). Individual development accounts and banks: A solid "match." FDIC Quarterly. Retrieved 
from https://www.fdic.gov/bank/analytical/quarterly/ 2007_vol1/idas-and-banks.html

Carlson, M. B. (2014). Financial counselor versus financial coach. Retrieved from http://afcpe.org/assets/publications/newsletter/Q4-2014.pdf

Carlson, M. B., Nelson, J. S., \& Skimmyhorn, W. (2016). Chapter 21. Military personal finance research. In J. J. Xiao (Ed.), Handbook of consumer finance research (2nd ed.). New York, NY: Springer Publishing.

Collins, J. M. (2014). Financial coaching: An asset building strategy. Asset Funders Notebook. Retrieved from http://assetfunders.org/images/pages/AFN_FinacialCoaching\%28WEB_version\%29.pdf

Collins, J. M., \& O'Rourke, C. M. (2011). Homeownership education and counseling: Do we know what works? Washington, DC: Research Institute for Housing America.

Collins, J. M., \& Schmeiser, M. D. (2012). The effects of foreclosure counseling for distressed homeowners. Journal of Policy Analysis and Management, 32(1), 83-106. http://dx.doi.org/10.1002/pam.21670

Collins, J. M., Schmeiser, M. D., \& Urban, C. (2013). Protecting minority homeowners: Race, foreclosure counseling and mortgage modifications. Journal of Consumer Affairs, 47(2), 289-310. http://dx.doi.org/10. 1111/joca.12006

Cox, P. (2008). Foreclosure reform among mortgage lending turmoil: A public purpose approach. Houston Law Review, 45(3), 683-744.

Davis, K., \& Kim, A. (2016). A behavioral approach to financial counseling. Retrieved from http://www.prof essionalfincounselingjournal.org/a-behavioral-approach-to- financialcounseling.html

Dew, J., \& Xiao, J. J. (2011). The financial management behavior scale: Development and validation. Journal of Financial Counseling and Planning, 22(1), 43-59.

Dobbie, W., \& Song, J. (2015). The impact of loan modifications on repayment, bankruptcy, and labor supply: Evidence from a randomized experiment. Retrieved from https://www.brown.edu/academics/economics/ sites/brown.edu.academics.economics/files/uploads/ Dobbie.pdf

Elliehausen, G., Staten, M. E., \& Lundquist, E. C. (2007). The impact of credit counseling on subsequent borrower credit usage and payment behavior. The Journal of Consumer Affairs, 41, 1-28.
Fedaseyeu, V., \& Hunt, R. (2015, November). The Economics of Debt Collection: Enforcement of Consumer Credit Contracts. FRB of Philadelphia Working Paper No. 15-43. Retrieved from https://papers.ssrn.com/ sol3/papers.cfm?abstract_id $=2411056$

Grable, J. E., \& Joo, S. (2001). A further examination of help-seeking behavior. Financial Counseling and Planning, 12(1), 55-74.

Griffiths, M. F., Baxter, S. M., \& Townley-Jones, M. E. (2011). The wellbeing of financial counselors: A study of work stress and job satisfaction. Journal of Financial Counseling and Planning, 22(2), 41-53.

Grinstead, M. L., Mauldin, T., Sabia, J. J., Koonce, J., \& Palmer, L. (2011). Saving for success: Financial education and savings goal achievement in individual development accounts. Journal of Financial Counseling and Planning, 22(2), 28-40.

Herbert, C. E., Turnham, J., \& Rodger, C. N. (2008). The state of the housing counseling industry. September ABT Associates. Retrieved from https://www.huduser. gov/portal/publications/hsg_counsel.pdf

Hunt, R. M. (2005). Whither consumer credit counseling? Philadelphia Fed Business Review Q4. Retrieved from https://www.philadelphiafed.org/consumer-credit-and-payments/publications

Jacobson, V. (2016). Using an evidence-based behaviorchange counseling model. The Professionalizing Field of Financial Counseling and Coaching Journal, 31-32.

Jefferson, A., Spade, J., Turnham, J., \& Moulton, S. (2012). Foreclosure counseling outcome study: Final report housing counseling outcome evaluation. Abt Associates. SSRN Electronic Journal, Retrieved from. http:// dx.doi.org/10.2139/ssrn.2112264

Kim, J., Garman, E., T., \& Sorhaindo, B. (2003). Relationship among credit counseling clients' financial wellbeing, financial behaviors, financial stressor events and health. Journal of Financial Counseling and Planning, 14(2), 75-87.

Lander, D. A., \& Loonin, D. (2005). Restoring 'non-profitness' and 'quality' to the credit counseling industry. Norton Bankruptcy Law Adviser, April.

Lienhardt, H. (2015). Financial coaching census 2015 insights from the financial coaching field. Retrieved from http://assetfunders.org/documents/AFN_Financial Coaching_Census_2015.pdf

Lind, S. M. (2011). The impact of consumer credit counseling on distressed mortgage loan losses. Stratmoor 
Group. Retrieved from https://www.nfcc.org/wp- content/uploads/2014/01/distressed_mortgage.pdf

Loonin, D., \& Plunkett, T. (2003). Credit counseling in crisis: The impact on consumers of funding cuts, higher fees and funding and aggressive new market entrants. Retrieved from https://consumerfed.org/pdfs/credit_ counseling_report.pdf

Mayer, N., Tation, P. A., Temkin, K., \& Calhoun, C. (2012). Has foreclosure counseling helped troubled homeowners? Evidence from the evaluation of the national foreclosure mitigation counseling program. Retrieved from https://www.urban.org/sites/default/files/publication/ 25046/412492-Has-Foreclosure-Counseling-HelpedTroubled-Homeowners-.PDF

New York City Department of Consumer Affairs. (2014). Research and implementation; findings for social service programs. Retrieved from https://www1.nyc.gov/ assets/dca/downloads/pdf/partners/Research- Building FinancialCounselingintoSocialServiceDelivery.pdf

Olson, E. O. (2007). Promoting homeownership among low income households. The Urban Institute, Opportunity and Ownership Project. Report Number, 2.

Public Policy Research Center, University of Missouri St. Louis. (2014). Summary of data collection, student loan borrower repayment program. Retrieved from http:// umsl.edu/ cefc/files/pdfs/EvaluationReport.pdf

Quercia, R., \& Cowan, S. M. (2008a). The Impacts of Community-based Foreclosure Prevention Programs. Housing Studies, 23(3), 461-483. http://dx.doi.org/10.1080/ 02673030802020627

Quercia, R., \& Spader, J. (2008b). Does homeownership counseling affect the prepayment and default behavior of affordable mortgage borrowers? Journal of Policy Analysis and Management, 27(2), 304-325. http://dx. doi.org/10.1002/pam.20326

Roll, S., \& Moulton, S. (2016). The impact of credit counseling on consumer outcomes: Evidence from a national demonstration program. Retrieved from http://gflec. org/wp-content/uploads/2016/04/Roll-Stephen-andMoulton- Stephanie-The-Impact-of-Credit-Counselingon-Consumer-Outcomes.pdf

Rowley, M. E., Lown, J. M., \& Piercy, K. W. (2012). Motivating women to adopt positive financial behaviors. Journal of Financial Counseling and Planning, 23(10), 47-62.
Sherraden, M., Jacobson, F. J., \& Birkenmaier, J. (2016). Chapter 10 Financial Social Work. In J. J. Xiao (Ed.), Handbook of consumer finance research (Vol. 2, pp. 115-127). New York, NY: Springer Publishing.

Williams, F. O. (2013). Behind the credit counseling curtain. Retrieved from http://www.foxbusiness.com/ features/2013/02/04/behind-credit-counseling-curtain. html

Williams, F. O. (2014). The 10 nonprofit consumer credit counseling agencies. Retrieved from http://blogs.creditcards.com/2016/04/struggling-debtors-help-makenonprofit-ceos- wealthy.php

Williams, F. O. (2015). Credit counselors turn to student debt. Retrieved from http://www.creditcards.com/ credit-card-news/credit-counselors-student-loan-debt1279.php\#ixzz473JdwAi3

Williams, F. O. (2016). Struggling debtors help make nonprofit CEO's wealthy: Taking Charge. A creditcards. com blog. Retrieved from http://blogs.creditcards.com/ 2016/04/struggling-debtors-help-make-nonprofit-ceoswealthy.php

Wilshusen, S. M. (2011). Meeting the demand for debt relief. Federal Reserve Bank of Philadelphia, Discussion Paper - Payment Cards Center. Retrieved from https:// getoutofdebt.org/wp-content/uploads/2013/07/SSRNid1908334.pdf

Xiao, J. J., Newman, B. M., Prochaska, J. M., Leon, B., Bassett, R. L., \& Johnson, J. L. (2004a). Applying the transtheoretical model of change to consumer debt behavior. The Journal of Financial Counseling and Planning, 15(2), 89-100.

Xiao, J. J., O'Neill, B., Prochaska, J. M., Kerbel, C. M., Brennan, P., \& Bristow, B. J. (2004b). A consumer education program based on the transtheoretical model of change. International Journal of Consumer Studies, 28(1), 55-65. http://dx.doi.org/10.1111/j.1470-6431. 2004.00334.x

Xiao, J. J., \& Wu, J. (2008). Completing debt management plans in credit counseling: An application of the theory of planned behavior. Journal of Financial Counseling and Planning, 19(2), 28-45.

Acknowledgments. The author thanks Carole Lander and others for their crucial help. 